\title{
Protoscolicidal Effects and Acute Toxicity of Essential Oil and Methanolic Extract of Cuminum cyminum Seeds
}

Amir Keyhani, Amir Tavakoli Kareshk, Razieh Tavakoli Oliaei, Hossein Mahmoudvand

\begin{abstract}
Surgical treatments were the gold standard for treatment of cystic echinococcosis (CE) until the last 30 years. Existing scolicidal agents such as hypertonic saline and silver-nitrate which have been used for inactivation of protoscoleces during surgery are associated with some serious adverse effects. The present study was designed to investigate in vitro scolicidal activity of Cuminum cyminum L. against protoscoleces of hydatid cysts and its acute toxicity in mice model. Protoscoleces were aseptically aspirated from sheep livers having hydatid cysts. Various concentrations of the essential oil (12.5- $100 \mu \mathrm{l} / \mathrm{mL})$ and methanolic extract $(12.5-100 \mathrm{mg} / \mathrm{mL})$ were used for 5 to $60 \mathrm{~min}$. Viability of protoscoleces was confirmed using eosin exclusion test $(0.1 \%$ eosin staining). Moreover, thirty-two male NMRI mice were used to determine the acute toxicity of C.cyminum.
\end{abstract}

C. cyminum methanolic extract at the concentrations of 100 and $50 \mathrm{mg} / \mathrm{ml}$ killed $100 \%$ protoscoleces after 10 and 20 minutes exposure. Moreover, all protoscoleces were killed upon 10 and 20 minutes of exposure to 50 and $25 \mu \mathrm{l} / \mathrm{mL}$ C. cyminum essential oil, respectively. The essential oil demonstrated no mortality up to the dose of $1 \mathrm{ml} / \mathrm{kg}$, but $25 \%$ mortality at dose of $2 \mathrm{ml} / \mathrm{kg}$ was occurred. The methanolic extract showed no mortality up to the dose of $4 \mathrm{~g} / \mathrm{kg}$. The obtained results indicated the potent scolicidal activity of C. cyminum with no significant toxicity which might be used as a natural scolicidal agent in hydatid cyst surgery. However, further investigation will be needed to confirm these results by checking in a clinical setting as a new scolicidal agent.

Keywords: Cumin; scolicidal effects; cystic echinococcosis; hydatid cyst; toxicity
Amir Keyhani, Amir Tavakoli Kareshk, Razieh Tavakoli Oliaei

Research Center for Hydatid Disease in Iran, Kerman University of Medical Sciences, Kerman, Iran.

Hossein Mahmoudvand

Razi Herbal Medicine Research Center, Lorestan University of Medical Sciences, Khorramabad, Iran.

Corresponding Author:

Hossein Mahmoudvand

e-mail:dmahmodvand@gmail.com

Submitted / Gönderilme: 19.01.2017

Accepted / Kabul: $\quad$ 07.03.2017
Revised / Düzeltme: 03.03.2017

\section{Introduction}

Hydatid disease or cystic echinococcosis (CE) is between the main neglected parasitic infections around the world which typically caused by the metacestodes form of the Echinococcus granulosus [1]. CE can grow slowly for several years up to the onset of clinical manifestations or as an accidental finding on some radiography examinations such as ultrasound (US) scan that demanded for not related reasons [2]. Clinical symptoms can indicate that the cyst is already problematical, e.g., cysts rupture, secondarily infections, or leaking and producing anaphylactic shock [2]. Since last decades the gold standard treatment for hydtidosis was surgery; whereas chemotherapy with albendazol, mebendazole and also PAIR (cyst puncture, aspiration, injection of chemicals and reaspiration) were then expanded which have progressively further supplemented or surprisingly replaced surgery [2]. When surgery is doing the use of influential scolicidal agents to avoid reappearance and secondary infection of hydatid cyst is compulsory. [3]. Recent investigations demonstrated 
or have shown that accessible scolicidal drugs because of having severe complications such as sclerosing cholangitis should be used with caution [4]. This indicated that discovery of a novel scolicidal agent with low complications and higher performance is one of the most important concerns of surgeons.

Of years ago until now, herbs and spices have been applied for prevention and treatment of a broad spectrum of illnesses such as infectious ones [5, 6]. Cuminum cyminum $\mathrm{L}$. (Apiaceae family) as an aromatic herb broadly demonstrated some medicinal features such as antidiarrhoeal, anti-diabetic, antioxidant, anti-epileptic, anti-stress, hepatoprotective and renoprotective, as well as anti-bacterial, and anti-fungal in modern medicine [8]. To the best of our knowledge, there have been no studies made on scolicidal effects of $C$. cyminum. Thus, this study was aimed to assess protoscolicidal activity of C. cyminum against protoscoleces of hydatid cysts and also its acute toxicity in mice.

\section{Materials and methods}

\section{Plant collection}

Seeds of C. cyminum were collected from the rural region of Bam district, Kerman province, Iran in May 2014. The plant materials were identified by a botanist of the Botany Department of Shahid Bahonar University, Kerman, Iran. A voucher specimen of the plant materials was deposited at the Herbarium of Department of Pharmacognosy of School of Pharmacy, Kerman University of Medical Science, Iran (KF 1357-1).

\section{Preparing of methanolic extract}

Air dried seeds $(100 \mathrm{~g})$ were extracted by percolation method with $80 \%$ methanol successively for $72 \mathrm{~h}$. in room temperature. The extract was passed through filter paper (Whatman No.3, Sigma, Germany) to remove plant debris. Finally, the extractwas concentrated in vacuum at $50^{\circ} \mathrm{C}$ using a rotary evaporator (Heidolph, Germany) and stored at $-20^{\circ} \mathrm{C}$, until testing [9].

\section{Isolation of essential oil}

One hundred grams of crushed seeds were subjected to hydrodistillation for $3 \mathrm{~h}$ using an all-glass clevenger-type apparatus. The essential oil obtained was dried over anhydrous sodium sulfate, and stored in darkness at $4^{\circ} \mathrm{C}$ in airtight glass vials closed until testing [10].

\section{Drug dilution}

For the preparation of dilutions of the C. cyminum essential oil, $0.1 \mathrm{~mL}$ of the essential oil was dissolved in $0.97 \mathrm{~mL}$ of normal saline. In addition, to enhance the dispersal of the essential oil in normal saline, $0.03 \mathrm{~mL}$ of Tween 20 (SigmaAldrich, St Louis, MO, USA) was added to the test tube. Serial dilutions were carried out to obtain the essential oil at the concentrations of 12.5 to $100 \mu \mathrm{l} / \mathrm{mL}$. To prepare different concentrations of methanolic extract, $100 \mathrm{mg}$ of the methanolic extract was dissolved in $1 \mathrm{~mL}$ normal saline and then serial dilution were performed to obtain the methanolic extract at the concentrations of $50,25,12.5 \mathrm{mg} / \mathrm{mL}$. The choice of doses was based on preliminary experiments, which also indicated that normal saline plus Tween $20 \mathrm{did}$ not cause effect on the growth of parasite.

\section{Collection of protoscoleces}

Hydatid cysts protoscoleces were collected from the livers of naturally infected sheep and goats slaughtered at Kerman abattoir, southeastern Iran. The hydatid fluid aspirated by a $50 \mathrm{~mL}$ syringe and aseptically transferred into a flask was left to set for $30 \mathrm{~min}$ for protoscoleces to settle down. The supernatant was discarded and the protoscoleces were washed two times with PBS ( $\mathrm{pH}$ 7.2) solution. The number of protoscoleces per $\mathrm{mL}$ was adjusted as $2 \times 10^{3}$ protoscoleces in $0.9 \% \mathrm{NaCl}$ solution with at least $90 \%$ viability rate.

\section{Effects on protoscolices}

To find out protoscolicidal effects of C. cyminum essential oil, $0.5 \mathrm{~mL}$ of the protoscoleces $\left(1 \times 10^{3} / \mathrm{mL}\right)$ solution was placed in test tubes. Then $0.5 \mathrm{~mL}$ of various concentrations of the essential oil and methanolic extract was added to each test tube, separately. The contents of the tubes were quietly mixed and then incubated at $37^{\circ} \mathrm{C}$ for $5,10,20$, and $30 \mathrm{~min}$. then the superior part was cautiously detached so as not to break off the protoscoleces.

\section{Viability test}

To do this, $50 \mu \mathrm{L}$ of $0.1 \%$ ( $1 \mathrm{~g}$ of eosin powder in 1,000 $\mathrm{ml}$ distilled water) eosin stain (Sigma-Aldrich, St Louis, MO, USA) was added to the residual settled protoscoleces and mixed softly. The superior part of the solution was throwing away after $10 \mathrm{~min}$ of incubation. After this time, protoscoleces was smeared on a glass slide, covered with a cover glass and tested under a light microscope. The live 
protoscoleces kept colorless and represented muscular motions and flame cell action, at the same time the dead protoscoleces captivated eosin and colored red (Fig 1). The percentages of viability of protoscoleces were determined by counting 300 protoscoleces. Moreover, normal saline and hypertonic saline $20 \%$ was applied as negative and positive control, respectively [11].

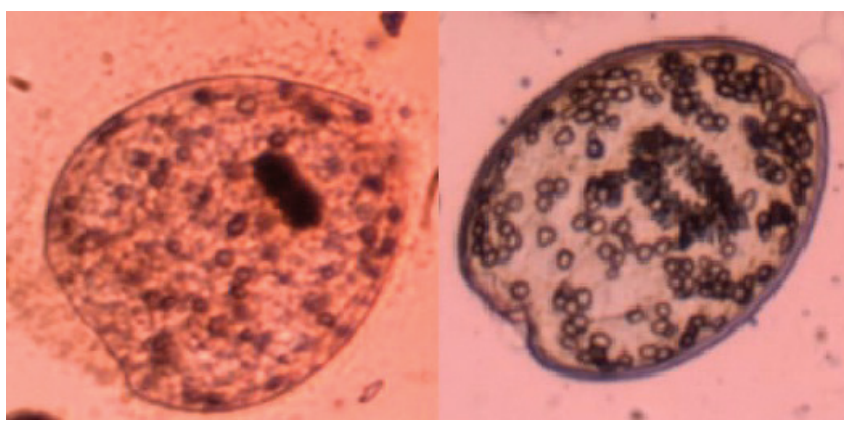

Figure 1. Death (left) and live (right) protoscoleces of hydatid cysts after exposure with $0.1 \%$ eosin.

\section{Animals}

Thirty-two male NMRI mice (6-8 weeks old) were obtained from the Animal Breeding Stock Facility of Razi Institute of Iran (Karaj, Iran). Animals were housed in a colony room with a $12: 12 \mathrm{~h}$ light/ dark cycle at $21 \pm 2^{\circ} \mathrm{C}$ and were handled according to standard protocols for the use of laboratory animals. The experimental procedures carried out in this study complied with the guidelines of the Kerman University of Medical Science (Kerman, Iran) for the care and use of laboratory animals (Permit no. 2016/279).

\section{Toxicity effects}

To determine the acute toxicity, various doses of C. cyminum essential oil (0.5-4 ml/kg) and methanolic extract (0.5-4 g/ $\mathrm{kg}$ ) were injected as intraperitoneally into groups of four mice and the mortality and morbidity was recorded after 24 h [12].

\section{Statistical analysis}

All the tests were performed in triplicate. Data analysis was carried out by using SPSS statistical package (version 17.0) (SPSS Inc., Chicago, IL, USA). To determine the acute toxicity, LD50 values were determined by the Probit test in SPSS software. In evaluation of protoscolicidal effects of $C$. cyminum, the difference between various concentrations was evaluated by ANOVA which followed by $t$ - test and $p$ values less than 0.05 were considered significant.

\section{Results \\ Protoscolicidal effects}

Table 1 shows scolicidal effects of C. cyminum methanolic extract at the various concentrations following different exposure times. C. cyminum methanolic extract at the concentrations of 100 and $50 \mathrm{mg} / \mathrm{ml}$ killed all over of protoscoleces after 10 and 20 minutes exposure, respectively. Likewise, lower concentrations of methanolic extract forced a postponed scolicidal activity. Table 2 shows $100 \%$ protoscoleces were killed upon 10 and 20 minutes of exposure to 50 and $25 \mu \mathrm{l} / \mathrm{mL}$ C. cyminum essential oil, respectively. Obtained results also confirmed that lower concentrations of C. cyminum essential oil had a belated scolicidal effects. The mortality rate of protoscoleces in the negative and positive control was 4.3 and $100 \%$ after 30 and 10 min exposure, respectively. These findings demonstrated that essential oil and methanolic extract of C. cyminum at all of concentrations had considerable $(p<0.05)$ scolicidal effects in comparison with the control group.

\section{Acute toxicity}

Acute toxicity effects of C. cyminum were determined on male NMRI mice. The essential oil demonstrated no mortality up to the dose of $1 \mathrm{ml} / \mathrm{kg}$, but $25 \%$ mortality at dose of $2 \mathrm{ml} / \mathrm{kg}$ was occurred. The methanolic extract showed no mortality up to the dose of $4 \mathrm{~g} / \mathrm{kg}$.

\section{Discussion}

From long time ago, antimicrobial property of remedial herbs has been logically revealed in experiments with essential oils, extracts and phytoconstituents [13]. Nowadays, essential oils as one of the most important herb formatives have effective antimicrobial activities because of owing two special features: their natural basis generally means appropriate safety to human and environment; and also because of low threat for rising of microbial resistance as a result of possessing components with a range of mechanisms of antimicrobial effects [6]. As reported by the World Health Organization (WHO), an perfect scolicidal drug qualified by its power at lesser concentrations, high efficiency in a brief time of contact, permanence in the 
Table 1. Protoscolicidal effects of C. cyminum methanolic extract against protoscoleces of hydatid cyst at various concentrations following various exposure times. Data are expressed as the mean $\pm S D(n=3)$.

\begin{tabular}{ccc}
\hline $\begin{array}{c}\text { Concentration of C.cyminum metabolic extract } \\
(\mathrm{mg} / \mathrm{mL})\end{array}$ & Exposure time $(\mathrm{min})$ & Mean of mortality rate (\%) \\
\hline & 10 & $100 \pm 0.0$ \\
& 20 & $100 \pm 0.0$ \\
100 & 30 & $100 \pm 0.0$ \\
& 60 & $100 \pm 0.0$ \\
& 10 & $83.5 \pm 2.12$ \\
& 20 & $100 \pm 0.0$ \\
& 30 & $100 \pm 0.0$ \\
& 60 & $100 \pm 0.0$ \\
& 10 & $37.5 \pm 3.53$ \\
& 20 & $72.5 \pm 3.53$ \\
& 30 & $100 \pm 0.0$ \\
& 60 & $100 \pm 0.0$ \\
& & \\
& 10 & $12.5 \pm 3.53$ \\
& 20 & $39.0 \pm 5.65$ \\
& 30 & $68.0 \pm 5.65$ \\
& 60 & $100 \pm 0.0$
\end{tabular}

attendance of cystic fluid, scolicidal skill indoor a cyst, minor toxicity, high ease of use, and capability for quick preparation [1]. To date, scolicidal activity of a range of chemical and natural products including hypertonic saline, silver nitrate and mannitol, selenium nanoparticles, honey and some plant extracts have been proven [14-19]. However, they are accompanying with some advers side effects for example biliary tract fibrosis and their usefulness is contentious. Our results revealed that C. cyminum essential oil at the concentrations of 50 and $25 \mu \mathrm{l} / \mathrm{mL}$ and methanolic extract at the concentrations of 100 and 50 $\mathrm{mg} / \mathrm{mL}$ killed $100 \%$ protoscoleces after 10 and 20 minutes exposure respectively. Therefore it could be concluded that scolicidal activity of C. cyminum particularly its essential oil is comparable with the existing scolicidal agents.
Based on the previous study, in the initially phytochemical analysis of $C$. cyminum extract the are some compounds such as terpenoids, phenols, flavonoids, and fatty acids [8]. Recently, Oroojalian et al [20] have recognized nineteen compounds in the essential oil of $C$. cyminum $\mathrm{L}$. from Mashhad, Iran, whereas the main components were cuminaldehyde (30.2\%), p-cymene (14.1\%), $\gamma$-terpinene (12.8\%), safranal (9.4\%), and $\beta$-pinene (6.4\%), respectively. In the other study on the chemical composition of $C$. cyminum L. from the Alborz mountain a-pinene (29.2\%), limonene (21.7\%), 1, 8-cineole (18.1\%), linalool (10.5\%), and a-terpineole (3.17\%) were found as the major compounds [21]. However, some factors such as geographical source and collecting time could influence on the chemical composition and functional activity of plant essential oils [22-24]. 
Table 2. Protoscolicidal effects of C. cyminum essential oil against protoscoleces of hydatid cyst at various concentrations following various exposure times. Data are expressed as the mean $\pm \mathrm{SD}(n=3)$.

\begin{tabular}{ccc}
\hline $\begin{array}{c}\text { C. cyminum essential oil concentration } \\
(\mu \mathrm{l} / \mathrm{mL})\end{array}$ & Exposure time $(\mathrm{min})$ & Mean of mortality rate (\%) \\
& & \\
& & $100 \pm 0.0$ \\
50 & 20 & $100 \pm 0.0$ \\
& 30 & $100 \pm 0.0$ \\
& 60 & $100 \pm 0.0$ \\
& 10 & $75.0 \pm 7.0$ \\
25 & 20 & $100 \pm 0.0$ \\
& 30 & $100 \pm 0.0$ \\
& 60 & $100 \pm 0.0$ \\
& & $52.6 \pm 3.53$ \\
& 10 & $82.3 \pm 4.9$ \\
& 20 & $100 \pm 0.0$ \\
& 30 & $100 \pm 0.0$ \\
& 60 & $5.0 \pm 2.82$ \\
& 10 & $8.5 \pm 2.52$ \\
& 20 & $61.0 \pm 6.1$ \\
& 30 & $100 \pm 0.0$ \\
& 60 & $1.6 \pm 1.15$ \\
& 10 & $2.6 \pm 1.15$ \\
& 20 & $3.0 \pm 0.5$ \\
& 30 & $4.6 \pm 1.5$
\end{tabular}

This indicated that some of these main components could be answerable for their scolicidal properties of this plant; while their accurate mechanisms of action are inadequately unstated [6]. However, previous investigations on antimicrobial mechanism of some terpenoids demonstrated that these components can manipulate permeability cell membranes and also arrived into the cell and disturb vital intracellular functions [25-27].

Regarding toxicity effects of C. cyminum, the obtained results that the essential oil had no mortality up to the dose of $2 \mathrm{ml} /$ $\mathrm{kg}$, but $25 \%$ mortality at dose of $4 \mathrm{ml} / \mathrm{kg}$ was occurred; while, the methanolic extract showed no mortality up to the dose of $4 \mathrm{~g} / \mathrm{kg}$. In a study Haroun et al (2002) demonstrated that diets containing $2 \%$ C. cyminum fruits were not any toxic effects to rats; whereas some problems such as disorder of growth and enterohepatonephropathy were reported in the rats fed a diet containing $10 \%$ C. cyminum fruits [28]. However, according to a toxicity classification, C. cyminum had no significant toxicity against male NMRI mice [29].

To conclude, the present study exhibited potent scolicidal activity of C. cyminum which could be used as a natural scolicidal agent to reduce the risk of protoscoleces spillage during hydatid cyst surgery. However, further investigation will be needed to confirm these results by checking in a clinical setting as a new scolicidal agent.

\section{Acknowledgments}

We would like to thank Dr. Ghasemi Kia for sample and data collection.

\section{Conflict of Interest}

The authors declare no conflict of interest 
Cuminum cyminum uçucu yağının ve bitkinin çekirdeklerinden hazırlanan metanollü ekstrenin akut toksisitesi ve protoskolisidal etkileri

\section{Öz}

Son 30 yıla kadar, kistik ekinokokkozis (CE) tedavisinde cerrahi yaklaşım en doğru seçim olarak görülmekteydi. Hipertonik tuz çözeltisi ve gümüş nitrat çözeltisi gibi skolisidal özellik gösteren çözeltiler cerrahi işlemler esnasında kistlerin inaktivasyonu için kullanılmakla birlikte bu çözeltilerin ciddi yan etkilere de neden olduğu bilinmektedir. Bu çalışmada, Cuminum cyminum L.'nin hidatik kist protoskoleseslerine karş1 in vitro skolisidal etkinliğine ek olarak oluşturulan fare modelinde akut toksisitesi de incelenmiştir. Protoskolesesler aseptik şartlarda hidatik kisti olan koyunların karaciğerlerinden aspire edilerek elde edilmiştir. Uçucu yağ $(12.5-100 \mu \mathrm{l} / \mathrm{mL})$ ve metanollü ekstre (12.5-100 mg/mL) farklı derişimlerde 5-60 dakika uygulanmıştır. Protoskoleseslerin canlılığı eosin eksklüzyon yöntemiyle (\%0.1 eozin boyama) ile tespit edilmiştir. Buna ek olarak, 32 erkek NMRI fare kullanılarak C.cyminum'un akut toksistesi çalışılmıştır. C.cyminum'un metanollü ekstresi 100 ve $50 \mathrm{mg} / \mathrm{ml}$ derişimlerde uygulandığında 10 ve 20 dakika maruziyet sonrasında protoskoleseslerin \%100'ünü öldürmüştür. C.cyminum'un uçucu yağı, 50 ve $25 \mu \mathrm{l} / \mathrm{mL}$ derişimlerde uygulandığında ise sırasıyla 10 ve 20 dakika maruziyet sonrasında tüm protoskoleseslerin öldüğü tespit edilmiştir. Uçucu yağ ile yapılan çalışmalarda $1 \mathrm{ml} / \mathrm{kg}$ doza kadar ölüm saptanmazken $2 \mathrm{ml} / \mathrm{kg}$ dozda ölüm oranı \%25’tir. Metanollü ekstre ile çalışıldığında ise $4 \mathrm{~g} / \mathrm{kg}$ doza kadar ölüm gerçekleşmemiştir. Elde edilen bulgular değerlendirildiğinde $C$. cyminum'un potansiyal skolisidal etkinliğine ek olarak ciddi bir toksiste göstermediği ve bu nedenle hidatik kist cerrahisinde bitkisel kaynaklı bir skolisidal olarak kullanılabileceği önerilmiş ancak önerininin doğrulanması için ileri klinik çalışmalara ihtiyaç duyulduğu da belirtilmiştir.

Anahtar kelimeler: Kimyon; skolisidal etki; kistik ekinokokkozis; hidatik kist; toksisite

\section{References}

1. World Health Organization (WHO) informal working group on echinococcosis. Bull WHO2009; 74: 231-42.

2. Kern P, Menezes da Silva A, Akhan O, Müllhaupt B, Vizcaychipi KA, Budke C, Vuitton DA. The echinococcoses: Diagnosis, clinical management and burden of disease. Adv Parasitol 2017;96:259-369.

3. Brunetti E, Kern P, Vuitton DA. Expert consensus for the diagnosis and treatment of cystic and alveolar echinococcosis in humans. Acta Tropica 2010; 114: 1-16.

4. Mahmoudvand H, Harandi MF, Shakibaie M, Aflatoonian MR, ZiaAli N, Makki MS, Jahanbakhsh S. Scolicidal effects of biogenic selenium nanoparticles against protoscolices of hydatid cysts. Int J Surg 2014; 12: 399-403.

5. Cos P, Vlietinck AJ, Berghe DV, Maes L. Anti-infective potential of natural products: how to develop a stronger in vitro 'proof-of-concept'. J Ethnopharmacol 2006; 106: 290-302.

6. Cowan MM. Plant products as antimicrobial agents. Clin Microbiol Rev 1999;12: 564-82.

7. Zargari A. Medicinal Plants, vol. II. Tehran University Press, Tehran. 1989, pp. 519-521.

8. Johri RK. Cuminumcyminum and Carumcarvi: An update. Pharmacogn Rev 2011; 5: 63-72.

9. Mahmoudvand H, Sharififar F, Rahmat MS, Tavakoli R, Dezaki ES, Jahanbakhsh S, Sharifi I. Evaluation of antileishmanial activity and cytotoxicity of the extracts of Berberis vulgaris and Nigella sativa against Leishmania tropica. J Vector Borne Dis 2014; 51: 294-9.

10. Tavakoli Kareshk A, Keyhani A, Mahmoudvan d H, Tavakoli Oliaei R, Asadi A, Andishmand M, Azzizian H, Babaei Z, ZiaAli N. Efficacy of the Bunium persicum (Boiss) essential oil against acute toxoplasmosis in mice model. Iran J Parasitol 2015; 10: 625-31.
11. Mahmoudvand H, Dezaki ES, Kheirandish F, Ezatpour B, Jahanbakhsh S, Harandi MF. Scolicidal effects of black cumin seed (Nigella sativa) essential oil on hydatid cysts. Korean J Parasitol 2014; 52: 653-9.

12. Mahmoudvand H, Tavakoli Oliaei R, Mirbadie SR, Kheirandish F, Tavakoli Kareshk A, Ezatpour B, Mahmoudvand H. Efficacy and safety of Bunium persicum (Boiss) to inactivate protoscoleces during hydatid cyst operations. Surg Infect (Larchmt) 2016;17:713-9.

13. Tiwari V, Roy R, Tiwari M. Antimicrobial active herbal compounds against Acinetobacter baumannii and other pathogens. Front Microbiol 2015;6:618.

14. Caglar R, Yuzbasioglu MF, Bulbuloglu E, Gul M, Ezberci F, Kale IT. In vitro effectiveness of different chemical agents on scolices of hydatid cyst. J Invest Surg 2008; 21: 71-5.

15. Mahmoudvand H, Asadi A, Harandi MF, Sharififar F, Jahanbakhsh S, Dezaki ES. In vitro lethal effects of various extracts of Nigella sativa seed on hydatid cyst protoscoleces. Iran J Basic Med Sci 2014; 7:1001-6.

16. Puryan K, Karadayi K, Topcu O, Canbay E, Sumer Z, Turan M, Karayalcin K, Sen M. Chlorhexidine gluconate: An ideal scolicidal agent in the treatment of intraperitoneal hydatidosis? World J Surg 2005; 29: 227-30.

17. Mahmoudvand H, Mirbadie SR, Sadooghian S, Fasihi Harandi M, Jahanbakhsh S, Saedi Dezaki E. Chemical composition and scolicidal activity of Zataria multiflora Boiss essential oil. J Essential Oil Res 2017; 29:42-7.

18. Kilicoglu B, Kismet K, Koru O, Tanyuksel M, Oruc MT, Sorkun K, Akkus MA. The scolicidal effects of honey. Adv Ther 2006; 23: 1077-83.

19. Jahanbakhsh S, Azadpour M, Kareshk AT, Keyhani A, Mahmoudvand H. Zataria multiflora Bioss: Lethal effects 
of methanolic extract against protoscoleces of Echinococcus granulosus. J Parasitic Dis 2016; 40: 1289-92.

20. Oroojalian F, Kasra-Kermanshahi R, Azizi M, Bassami M. Phytochemical composition of the essential oils from three Apiaceae species and their antibacterial effects on food-borne pathogens. Food Chem 2010; 120:765-70.

21. Mohammadpour H, Moghimipour E, Rasooli I, Fakoor MH, AlipoorAstaneh S, Sara ShehniMoosaie S, Jalili Z. Chemical composition and antifungal activity of Cuminum cyminum L. essential oil from Alborz mountain against Aspergillus species. Jundishapur J Nat Pharm Prod 2012; 7: 50-5.

22. Yesil Celiktas O, Hames Kocabas EE, Bedir E, Vardar Sukan F. Antimicrobial activities of methanol extracts and essential oils of Rosmarinus officinalis, depending on location and seasonal variations. Food Chem 2007; 100: 553-9.

23. Saedi Dezaki E, Mahmoudvand H, Sharififar F, Fallahi S, Monzote L, Ezatkhah F. Chemical composition along with anti-leishmanial and cytotoxic activity of Zataria multiflora. Pharm Biol 2015; 8: 1-7.

24. Mahmoudvand $H$, Tavakoli R, Sharififar F, Minaie K, Ezatpour B, Jahanbakhsh S, Sharifi I. Leishmanicidal and cytotoxic activities of Nigella sativa and its active principle, thymoquinone. Pharm Biol 2014; 4: 1-6.

25. Ezatpour B, Saedi Dezaki E, Mahmoudvand H, Azadpour $\mathrm{M}$, Ezzatkhah F. In vitro and in vivo antileishmanial effects of Pistacia khinjuk against Leishmania tropica and Leishmania major. Evid Based Complement Alternat Med 2015; 2015:149707.

26. Cristani M, D’Arrigo M, Mandalari G, Castelli F, Sarpietro MG, Micieli D, Venuti V, Bisignano G, Saija A, Trombetta D. Interaction of four monoterpenes contained in essential oils with model membranes: Implications for their antibacterial activity. J Agric Food Chem 2007; 55: 6300-8.

27. Mahmoudvand H, Saedi Dezaki E, Ezatpour B, Sharifi I, Kheirandish F, Rashidipour M. In vitro and in vivo antileishmanial activities of Pistacia vera essential oil. Planta Medica 2016; 82: 279-84.

28. Haroun EM, Mahmoud OM, Adam SE. Effect of feeding Cuminum cyminum fruits, Thymus vulgaris leaves or their mixture to rats. Vet Hum Toxicol 2002;44:67-9.

29. Loomis TA, Hayes AW. Loomis's Essentials of Toxicology. Academic Press. Inc., San Diego, CA. 1996, pp. 205-248. 